\title{
Leadership in a school context: how leadership styles are associated with leadership outcomes
}

\section{Hasan Hariri}

Faculty of Teacher Training and Education, Universitas Lampung, Indonesia hasan.hariri@staff.unila.ac.id

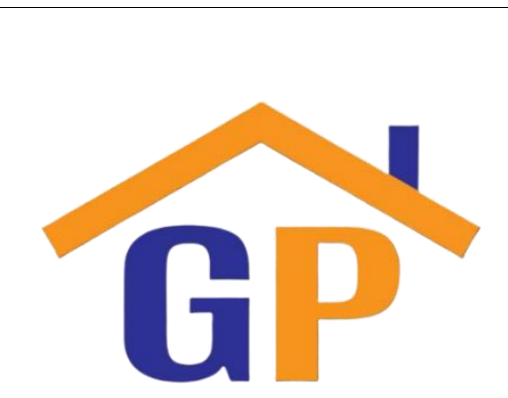

Article History

Received on 8 September 2020

Revised on 14 September 2020

Accepted on 15 September 2020

\begin{abstract}
Purpose: This paper aims at examining how principal leadership styles are associated with leadership outcomes in an Indonesian school context.

Research Methodology: Survey data were collected using MLQ $5 \mathrm{X}$-Short and a demographic questionnaire completed by 475 teachers in 36 junior high schools in the Province of Lampung, Indonesia. With the help of SPSS version 22, the collected data were initially analyzed using descriptive statistics and then Pearson product-moment correlation.
\end{abstract}

Results: Results show that transformational and transactional leadership styles are positively and significantly associated with the leadership outcomes, but the laissez-faire leadership style is negatively and significantly associated with the leadership outcomes.

Limitations: This paper used a quantitative research approach and is acknowledged for being limited to using the survey questionnaire so that it could not explain why and how principal leadership styles affect such leadership outcomes.

Contribution: This paper theoretically and practically contributes to the body of knowledge, particularly concerning leadership styles and their outcomes.

Keywords: School leadership, Leadership outcomes, Principal, Teacher

How to cite: Hariri, Hasan. (2020). Leadership in a school context: how leadership styles are associated with leadership outcomes. International Journal of Financial, Accounting, and Management, 2(2), 159-170.

\section{Introduction}

The leadership literature in the education sector is enormous, in part, because education is essential for the development of human resources that will lead to economic growth of countries (e.g., Hariri, Monypenny, \& Prideaux, 2012; Hourani \& Stringer, 2015; Nguni, Sleegers, \& Denessen, 2006; Sofo, Fitzgerald, \& Jawas, 2012; Storey, 2004). Thus, the various drivers of school principal leadership styles in association with school leadership outcomes become a vital basis of schools and economic growth plans of many governments (Hariri et al., 2012). As shown by Hariri, Monypenny, and Prideaux (2014), for school effectiveness and students' future success, effective school leadership should be in place. The success of schools, as well as students are significantly influenced by school principals.(Gurr, Drysdale, \& Mulford, 2005).

The principal capability substantially influences school leadership for adopting more collaborative leadership styles and involving others in making collaborative decision (e.g., Barnett \& McCormick, 2003; Ng, Wang, \& Liu, 2015; Pashiardis, 1993; Steyn, 2015; Williams, 2008). That is why principalship is said to be a key to economic growth plans of many governments (e.g., Hallinger, 2011; 
Hallinger \& Walker, 2011). To some extent, development of leadership has been much researched and underpinned school policy activities (Mertkan, 2011, p. 79). Thus, principals should be very seriously prepared (Siegrist, 1999). In fact, it is so important that as Thomas and Kearney (2010, p. 10) assert that, until recently, effective principalship has been found to be a key factor in student achievement and school improvement. However, there are few studies about leadership behaviours (Gemeda \& Lee, 2020; Little, Gooty, \& Williams, 2016; Vullinghs, De Hoogh, Den Hartog, \& Boon, 2018), and little is known about studies of school leadership in the Asian context (Raihani, 2008; Wong \& Wong, 2005). Hence, this paper helps close a part of the wide gaps of leadership research in the Asian context, in addition to the other three published papers resulted from the research project.

This paper, Paper 4, is about Leadership in a School Context: How Leadership Styles Are Associated with Leadership Outcomes. The other three previous papers were published in 2012, 2014, and 2016 respectively. Unlike the three previous papers, Paper 4 includes leadership outcomes (extra effort, effectiveness, and satisfaction), in addition to leadership styles. Paper 1 examined whether teacher job satisfaction could be significantly predicted by decision-making styles (Hariri et al., 2012); whereas, Paper 2 investigated leadership styles in relation to decision-making styles (Hariri et al., 2014), and Paper 3 examined the congruency of data from Indonesian schools with the Anglophile and Western literature concerning principal leadership styles, decision-making styles and teacher job satisfaction (Hariri, Monypenny, \& Prideaux, 2016).

The whole project that produced these papers included a significant review of the literature that produced the following framework for the whole project: First, that there is a large but mainly Anglocentric and Western literature on the topic of the project. Second, that within this literature, relationships exist between: (1) laissez-faire, transactional, and transformational leadership styles, (2) avoidant, spontaneous, dependent, intuitive, and rational decision-making styles, (3) nine job satisfaction facets (communication, contingent rewards, co-workers, fringe benefits, nature of work, operation conditions, pay, promotion, and supervision), (4) four demographic variables (sex, teacher certification, school location, and marital status). Third, that these relationships may range from highly positive to highly negative. Fourth, that given the mainly Anglocentric Western literature on the topic of the project, the significant issue for the project was to get good data for Indonesia to underpin the conclusions for each of the papers. Thus, this project breaks new academic ground by analysing the Indonesian context instead of the more Anglocentric focus of other studies.

For the whole research project, to randomly select prospective participants from public junior high schools in Lampung Province, sampling with three stages was employed (Hariri et al., 2016). Stage 1, that is, primary units, random sampling started with geographic districts, where six districts (Lampung Tengah, Lampung Selatan, Pesawaran, Pringsewu and Tanggamus, and Bandar Lampung) out of the 15 districts were chosen. Stage 2, that is, secondary units, where 37 schools were selected in the six districts. In Stage 3, that is, tertiary units, 518 out of 11,401 teachers and 37 principals (Kemdiknas, 2009) was chosen from the schools previously selected. Based on $95 \%$ level of confidence, such size of the sample is considered greater than the recommended size of sample (Gray, 2004).

There were four questionnaires used for the whole Project, these were the three standard survey questioners: the Multifactor Leadership Questionnaire (MLQ) Form 5X-Short (Bass \& Avolio, 2004), the General Decision-Making Style (GDMS) questionnaire (Scott \& Bruce, 1995), and the Job Satisfaction Survey (JSS) (Spector, 1985), and a self-designed demographic questionnaire. The demographic questionnaire was particularly developed for the whole project and is employed to dedepict demographics of the participants: sex, marital status, school location, teacher certification, and tenure with current principal. Data collected through these questionnaires are teacher reported data and actions of principals are perceived actions interpreted by teachers.

Within the above project framework, this paper investigates associations between leadership styles exhibited by the principals (laissez-faire, transactional, and transformational) and teacher-perceived leadership outcomes (extra effort, satisfaction, and effectiveness) in the context of Lampung public junior high schools, Indonesia. Three study questions were formulated to guide this paper: (1) What is 
the association between transformational leadership style and leadership outcomes (extra effort, satisfaction, and effectiveness)? (2) What is the association between transactional leadership style and leadership outcomes (extra effort, satisfaction, and effectiveness), (3) What is the association between laissez-faire leadership style and leadership outcomes (extra effort, satisfaction, and effectiveness) in the context of Lampung schools, Indonesian?

What is meant, in this paper, by the leadership styles as well as leadership outcomes is that the principals exhibit their leadership styles, whereas the teachers perceive the leadership styles exhibited by the principals as being laissez-faire, transactional, or transformational. This manuscript investigates whether leadership styles (exhibited by the principals) as perceived by teachers are associated with the extra effort, satisfaction, and effectiveness. As respondents, the teachers rated the principal leadership styles and leadership outcomes by completing the leadership questionnaire (MLQ).

For this paper, it is assumed that: (1) laissez-faire leadership style is negatively and significantly associated with leadership outcomes (extra effort, satisfaction, effectiveness) in an Indonesian school context. (2) Transactional leadership style is positively and siginificantly associated with leadership outcomes (extra effort, effectiveness, satisfaction) in an Indonesian school context. (3) Transformational leadership style is positively and siginificantly associated with leadership outcomes (extra effort, effectiveness, satisfaction) in an Indonesian school context.

\section{Literature review}

\subsection{Leadership styles}

The MLQ comprises three leadership styles and three leadership outcomes (Bass \& Avolio, 2004). This paper focuses on the associations between these two components. In this paper, school leadership aspect of the leadership literature in the education sector interests the author; this paper uses leadership styles as defined by Bass (1997) and studies on school principal leadership styles (laissez-faire, transactional, and transformational leadership styles) (Bass, 1997; Northouse, 2007) by means of the MLQ 5X-Short (Bass \& Avolio, 2004).

Regarding leadership styles as Hariri et al. (2014) asserted, a priori findings of this paper would expect to support Bass' augmentation effect theory (Bass, 1985, 1999) as well as Judge and Piccolo's findings (Judge \& Piccolo, 2004, p. 755). Hence, when school leaders need to remain effective and to attain leadership outcomes, they need to become more transformational and transactional, but to elude laissezfaire. Bass (1999) claimed that transactional leadership effectiveness is strengthened by transformational leadership. Autonomy and challenging work are nurtured by transformational leadership. Transformational leadership has made followers' satisfaction become increasingly vital. On the contrary, laissez-faire leadership greatly leads to followers' conflict, ineffectiveness, and dissatisfaction. The finding indicates that transformational leadership enhances the effect from transformational leadership better than that from transactional leadership (Judge \& Piccolo, 2004, p. 755). A priori, it would be expected that despite being not mutually exclusive, transformational leadership and transactional leadership are distinct (Judge \& Piccolo, 2004).

\subsection{Leadership outcomes}

This paper is about the teacher-perceived school principal leadership outcomes (extra effort, , satisfaction, effectiveness), all are aspects of the leadership literature in the education sector. The term 'leadership outcomes' is a wide topic; for example, the response to leadership outcomes could be by a range of stakeholders, for example by students, by teachers, or by external stakeholders; furthermore, the outcome could be in a range of attributes, for example in student learning, in teacher development, in the school structure, or in community stakeholders. However, the standard questionnaire used in this paper (the MLQ 5X-Short) (Avolio \& Bass, 2004) focuses on extra effort, satisfaction, and effectiveness. However, all of the studies that have been found were carried out in a non-school and in a non-Indonesian context (e.g., Alloubani, Abdelhafiz, Abughalyun, Edris, \& Almukhtar, 2015; Amirul \& Daud, 2012; Bennett, 2009; Nordin, 2013). 
This paper focuses on teacher-perceived leadership outcomes (extra effort, satisfaction, effectiveness) in an Indonesian school context. A priori, regarding leadership outcomes, it would be expected that the findings suggest significant associations between the three leadership styles and leadership outcomes.

\section{Research methodology}

The data for this paper came from the MLQ 5X-Short (Bass \& Avolio, 2004) plus the demographic questionnaire. The MLQ questionnaire measures principal leadership styles and leadership outcomes; the questionnaire was completed by the teachers. The principals exhibited these variables, but this paper examines these variables according to the perceptions of the teachers $(n=475)$, rather than the perceptions of the principals. In MLQ, there are only the three leadership outcomes. Leadership outcomes are what teachers perceive based on their feeling of the impacts of teacher-perceived principal leaderships styles. Participants rated principals on a five-point Likert rating scale ranging from not at all to frequently, if not always, with scores ranging from 0 to 4 (Bass \& Avolio, 2004).

Regarding scoring, the scores of the MLQ scale are mean scores for the scale items. The score is derived by calculation as follows: sum the items and divide by the number of items making up the scale. In case of an item being left blank, the score is obtained using the total for that scale which is divided by the number of items answered. The number of scales is as follows: (1) nine scales measuring three leadership styles: laissez-faire (one scale consisting of four items), transactional leadership (three scales consisting of 12 items), and transformational leadership (five scales consisting of 20 items), and (2) three scales measuring outcomes of leadership (three scales consisting of: extra effort with three items, satisfaction with two items, and effectiveness with four items). (Bass \& Avolio, 2004, p. 108).

Findings of studies suggest the MLQ Form 5X-Short consistency. For example, Antonakis, Avolio, and Sivasubramaniam (2003) found the nine factors best representing the factor structure underlying the MLQ Form 5X-Short instrument. In similar line, earlier research findings carried out by Avolio, Bass, and Jung (1999), revealed that the questiomnnaire was higly consistent in estimating factor loadings, interrelationships among factors, and reliability. Recently, Haj and Jubran (2016) examined the reliability of the instrument for its internal consistency resulting a Cronbach's $\alpha$ of 0.96.

More notably, Bass and Avolio (2004, p. 79) examined the MLQ nine-factor model which included 2003 nornative samples and used Confirmatory Factor Analysis (CFA). They revealed conclusive findings that the model showed the best fit with a clear consistency pattern across the corresponding results by participant and by region. The nine factor model comprises: 1) II (A) or Idealised Influence (Attribute), 2) II (B) or Idealised Influence (Behaviour), 3) IM or Inspirational Motivation, 4) IS or Intellectual Stimulation, 5) IC or Individualised Consideration, 6) CR or Contingent Reward, 7) MBEA or Management-by-Exception (Active), 8) MBEP or Management-by-Exception (Passive), and 9) LF (Laissez-Faire).

The MLQ had high reliabilities which exceeded standard cut-offs for internal consistency suggested in the literature. Each leadership factor scale and the total items had reliabilities ranging from 0.74 to 0.94 . (Bass \& Avolio, 2004, p. 48). Alpha $(\alpha)$ scores ranging from 0.60 to 0.70 suggest adequate reliabilities (Yellen, Cella, Webster, Blendowski, \& Kaplan, 1997). Muenjohn and Armstrong (2008, pp. 9-10) supported the acceptable reliabilities of the instrument, where they reported the Thai MLQ version with a Cronbach's $\alpha$ of 0.87) and the original one with a Cronbach's $\alpha$ of 0.86 as well as its acceptable construct validity. Their findings indicate successful in sufficiently capturing the factor constructs of the full leadership approach. Consequently, researchers are confident to use the instrument to assess the factors that represent the leadership styles and outcomes.

However, a different evidence is from Japan. Fukushige and Spicer (2011) carried out a comparative study using the MLQ Form 5X-Short (Bass \& Avolio, 2000). They compared leadership preferences of British and Japanese followers. The Japanese sample comprised 59 females and 207 males, while the British one comprised 28 females and 97 males. From the 36 items of the full-range leadership, they used 32 items, excluding the four items of laissez-faire leadership style. They removed the four items 
due to not receiving support in their previous research (see Aya \& David, 2007). The MLQ in the Japanese version was addressed to the Japanese repondents, while the English version was addressed to the British respondents They also modified the original Likert rating scale, that is, they employed the scale ranging from 1 (strongly disagree) to 5 (strongly agree).

They used Cronbach's $\alpha$ to explore Bass and Avolio's leadership scales (Bass \& Avolio, 2000). Their study for the Japanese sample revealed low reliability for four scales (IIA, CR, MBEA, and MBEP). These factors did not fulfil the adequate scores of Cronbach's $\alpha(0.6)$. This indicates that, for the Japanese case, that the findings do not support Bass' claim of construct universality of the instrument despite being for four scales (Bass, 1996). However, for the British case, the number of the scales which did not meet the acceptable scores of Cronbach's (0.6) was only two scales (IIA and IS) (Price \& Mueller, 1986). For comparation, the result of independent samples t-test used to test leadership scales between the two different samples revealed different preferences in followers' leadership between Japan and the UK. In terms of universality, however, unlike transactional leadership, transformational leadership was found to be more effective and active across a variety of situations including in schools due to transformational ledership being found as universal style of leadership (Hamdani, 2018).

This paper employed Cronbach's $\alpha$ and item-total correlations to check the internal consistency for the instrument. It met acceptable scores of Cronbach's $\alpha$ (exceeding 0.7 ) with the values of mostly above 0.3 for the item-total correlations.

\section{Results and discussions}

\subsection{Results}

\section{Results of descriptive statistics}

Descriptive statistics are used for both sample demographics and variables. Results of descriptive statistics for demographics of the sample of 475 teachers who completed the survey are described here.

In terms of sex balance, $56.4 \%$ of respondents were female teachers and $43.6 \%$ were male teachers. This is consistent with the reality that female teachers dominate teaching in Indonesia. But today men continue to outnumber women particularly in principal positions similar to the trends across APEC countries (Craig, Kraft, \& Du Plessis, 1998, p. 5). The surveyed teachers have been mostly: married (94.9\%), between 40 and 49 years old (52.8\%), had been awarded an undergraduate degree $(76.4 \%)$ and working with current principals for $1-2$ years. It is assumed that this tenure with the principal is the shortest time for the teachers to be able to effectively identify principals' behaviors.

This paper used descriptive statistics to depict the attributes of the variables including mean (M), standard deviation (SD), skewness, and kurtosis (see Table 1.

Table 1: Summary of descriptive statistics $(n=475)$

\begin{tabular}{lcccc}
\hline \multicolumn{1}{c}{ Variables $^{1}$} & Mean & Standard Deviation & Skewness & Kurtosis \\
\hline Principal leadership styles: & & & & \\
Laissez-faire & 0.819 & 0.674 & 0.642 & -0.423 \\
Transactional & 2.040 & 0.490 & -0.261 & \\
Transformational & 2.509 & 0.560 & -0.406 & -0.091 \\
\hline Leadership outcomes: & & & & \\
Extra efforts & 2.482 & 0.797 & -0.415 & -0.094 \\
Satisfaction & 2.581 & 0.950 & -0.668 & 0.117 \\
Effectiveness & 2.612 & 0.983 & -0.589 & -0.234 \\
\hline
\end{tabular}

Source: Data analysis of this paper

Table 2 shows the variables used in this paper: principal leadership styles and leadership outcomes (extra effort, satisfaction, and effectiveness) as perceived by teachers with the scores of mean, standard deviation, skewness, and kurtosis. The means of principal leadership styles as perceived by teachers in this paper from the highest to the lowest, ranging from 0 to 4 , are as as follows: mean of transformational was the highest $(\mathrm{M}=2.51, \mathrm{SD}=0.56)$, followed by mean of transactional $(\mathrm{M}=2.04$, 
$\mathrm{SD}=0.49)$ and mean of laissez-faire $(\mathrm{M}=0.82), \mathrm{SD}=0.67)$ (Bass \& Avolio, 2004). As teachers percieved, assessed using the MLQ 5X-Short, and analyzed using descriptive statistics, the leadership styles exhibited by the principals were all the three leadership styles. Nevertheless, the principals most frequently demonstrated transformational leadership style, followed by transactional leadership style, and scarcely displayed laissez-faire leadership style.

The descrptive statistics have been presented, then assumptions of Pearson correlation need to be checked before employing the correaltion.

\section{Assumptions for Pearson correlation}

Assumptions for Pearson correlation used for the data analysis, as for other parametric tests, are initially examined to ensure the data to be parametric (Field, 2009, p. 132). These examined assumptions as classified by Pallant (2007) are: continuous measures, random sampling, normality, observation independence, and variance homogeneity. All such assumptions were confirmed during the processing of the data for this paper. The assumption of continuous measures was executed by rescaling the qualitative data obtained from the survey into quantitative data, following the method of Bass and Avolio (2004). The random sampling assumption was confirmed throughout the phase of research design. The normality assumption was examined using skewness and kurtosis in which the data were normally distributed (both skewness and kurtosis values ranging from the +1 to -1 range), a much more stringent criterion than the +2 to -2 range criterion as suggested by Garson (2010). Last, the assumption of homogeneity of variances was tested using Lavene's test by doing ANOVA. Table 2 shows equal variances for all the respondents $(\mathrm{F}(1,473) \geq 0.05$, NS).

Table 2: variance homogeneity test

\begin{tabular}{lllll}
\hline & Levene Statistic & df1 & df2 & Sig. \\
\hline Laissez-faire leadership & 0.609 & 1 & 473 & 0.435 \\
Transactional leadership & 0.126 & 1 & 473 & 0.723 \\
Transformational leadership & 0.295 & 1 & 473 & 0.587 \\
Extra effort & 1.241 & 1 & 473 & 0.266 \\
Satisfaction & 4.277 & 1 & 473 & 0.039 \\
Effectiveness & 0.118 & 1 & 473 & 0.732 \\
\hline
\end{tabular}

Source: Analysis of survey data

The leadership outcomes in this study are three: extra efforts, satisfaction, and effectiveness. Effectiveness had the highest mean $(M=2.61, S D=0.98)$. Satisfaction $(M=2.58, S D=0.95)$ had a slightly lower mean than effectivness, followed by mean extra efforts $(\mathrm{M}=2.48, \mathrm{SD}=0.80)$. The leadership styles (laissez-faire, transactional, and transformational) had relationships with the leadership outcomes. Once the descriptive analysis was completed, Pearson product-moment correlation by means of SPSS version 22 was applied to answer the research questions as described below.

\section{Results of Pearson Correlation}

Relationship between the principal leadership styles and leadership outcomes are examined in this paper. It is essential to highlight that, based on the descriptive statistics analysis previously described, the school leaders displayed all the three leadership styles, where transformational leadership style was most frequently displyed, folloewed by transactional leadership style, but laissez-faire leadership style was hardly displayed. These results are consistent with previous studies, see for example Hariri et al. (2014).

Table 3 shows the relationships resulted from the data analysis using Pearson product-moment correlation by means of SPSS version 22 . 
Table 3: relationships between variables $(n=475)$

\begin{tabular}{|c|c|c|c|c|c|c|c|}
\hline No. & Variable & 1 & 2 & 3 & 4 & 5 & 6 \\
\hline 1 & Transformational leadership & 1 & & & & & \\
\hline 2 & Transactional leadership & $0.784 * * *$ & 1 & & & & \\
\hline 3 & Laissez-faire leadership & $-0.327 * * *$ & $-0.228 * * *$ & 1 & & & \\
\hline 4 & Extra effort & $0.782 * * *$ & $0.670 * * * *$ & $-0.296 * * *$ & 1 & & \\
\hline 5 & Effectiveness & $0.702 * * *$ & $0.649 * * *$ & $-0.304 * * *$ & $0.773 * * *$ & 1 & \\
\hline 6 & Satisfaction & $0.704 * * *$ & $0.643 * * *$ & $-0.344 * * *$ & $0.756 * * *$ & $0.742 * * *$ & 1 \\
\hline
\end{tabular}

$* \mathrm{p}<0.05, * * \mathrm{p}<0.01, * * * \mathrm{p}<0.001$

Source: Data analysis of this paper

The results shown in Table 3 are the answers to the study questions investigated in this paper. Below are the results and discussion of each research question (RQ) in detail.

\section{Result of $R Q 1$}

RQ1 is "What is the association between transformational leadership style and leadership outcomes (extra effort, satisfaction, and effectiveness)?" Table 3 shows the answer to the first research question. Result shows that transformational leadership style was positively and significantly associated with the three leadership outcomes: extra effort $(r=0.782, p<0.001)$, satisfaction $(r=0.704, p<0.001)$, and effectiveness $(r=0.702, p<0.001)$. These results suggest that the principal transformational leadership style has the highest association with extra effort, followed by teacher satisfaction with leader, and leader effectiveness respectively.

\section{Result of $R Q 2$}

RQ 2 is "What is the association between transactional leadership style and leadership outcomes (extra effort, satisfaction, and effectiveness)?" Table 3 shows results as the answer to the second research question. Result shows that transactional leadership style was positively and significantly associated with the three leadership outcomes: extra effort $(r=0.670, p<0.001)$, satisfaction $(r=0.643, p<0.001)$, and effectiveness $(r=0.649, p<0.001)$. These results suggest that the principal transactional leadership style has the highest relationship with teacher extra effort, followed by teacher effectiveness, and teacher satisfaction respectively.

\section{Result of $R Q 3$}

RQ 3 is "What is the association between laissez-faire leadership style and leadership outcomes (extra effort, satisfaction, and effectiveness) in the context of Lampung schools, Indonesian?" Table 3 shows results as the answer to the third research question. Result shows that laissez-faire leadership style was negatively and significantly associated with with the three leadership outcomes: extra effort $(\mathrm{r}=-0.296$, $p<0.001)$, satisfaction $(r=-0.344, p<0.001)$, and effectiveness $(r=-0.304, p<0.001)$. These results suggest that the principal laissez-faire leadership styles have the highest but negative relationship with teacher extra effort of the teachers, followed by teacher effectiveness, and teacher satisfaction respectively.

\subsection{Discussion}

In recent years, the studies of leadership outcomes have explored a range of attributes connected to outcomes and to a range of stakeholders' perceptions of the impact of leadership actions and policy (see, for example, Alloubani et al., 2015; Amirul \& Daud, 2012; Bennett, 2009; Nordin, 2013). However, all of the studies were found to be carried out in organizations other than schools and in countries other than an Indonesian context. Therefore, this paper focuses on teacher-perceived leadership outcomes (extra effort, satisfaction, and effectiveness) in relation to leadership styles as measured using the MLQ 5X-Short developed by Bass and Avolio (2004) in Lampung schools in Indonesia. 
As early outlined, this paper studied three research questions. Findings show that: (1) transformational leadership style was positively and significantly associated with the three leadership outcomes: extra effort, satisfaction, and effectiveness, (2) transactional leadership style was positively and significantly associated with the three leadership outcomes: extra effort, satisfaction, and effectiveness, but (3) laissez-faire leadership style was negatively and significantly associated with with the three leadership outcomes: extra effort, satisfaction, and effectiveness.

These findings essentially contribute to the literature as well as to the development of the school system of Indonesia. More specifically, these findings provide empirical and theoretical contributions to the body of knowledge concerning leadership theories in ways, particularly, by determining the extent to which leadership outcomes are influenced by leadership styles. There are previous research results relevant to this paper. These research results describe these three leadership styles: (1) laissez-faire, (2) transactional, and (3) transformational in relation to leadership outcomes (extra effort, satisfaction, and effectiveness).

In general, the findings of this paper support those of earlier studies (e.g., Alloubani et al., 2015; Amirul \& Daud, 2012; Casida \& Parker, 2011; Nordin, 2013) focusing on how leadership styles are associated with leadership outcomes measured by means of the MLQ 5X-Short. It could be said that the findings are conclusive that is, either transformational leadership or transactional leadership is positively associated with such leadership outcomes as extra effort, satisfaction, and effectiveness; nevertheless, laissez-faire leadership is negatively associated with the three leadership outcomes. Thus, this ype of leadership needs to be avoided due to its negative impacts on the ledership outcomes. It has an attribute of "passive-avoidant behaviour toward addressing challenges" (Ritchie et al., 2020, p. 8).

Specifically, the finding that transformational leadership style and leadership outcomes is positively and significantly associated supports earlier research results (Alloubani et al., 2015; Álvarez, Lila, \& Castillo, 2012; Casida \& Parker, 2011; Ismail, Ibrahim, Ali, Dawi, \& Ariff, 2015; Keegan \& Den Hartog, 2004; Lin, MacLennan, Hunt, \& Cox, 2015; Molero, Cuadrado, Navas, \& Morales, 2007; Nielsen, Yarker, Brenner, Randall, \& Borg, 2008; Nordin, 2013).

In particular, Casida and Parker (2011, p. 481) found that, in addition to being positively and significantly associated with the leadership outcomes (extra effort, effectiveness, and satisfaction), transformational leadership style is also the best predictor for these outcome variables. Moreover, transformational leadership style best predicts teacher job satisfaction, out of the three leadership styles (Hariri et al., 2016). Besides, transformational leadership style has the strongest correlation amongst all leadership styles with leadership outcomes (Alloubani et al., 2015, p. 294). The findings of this paper are consistent with the earlier ones. In recent research, it was found that the leadership outcomes (satisfaction, extra-effort, and effectiveness) are also associated with emotional intelligence in transformational leadership (Biswas \& Rahman, 2017). In particular, Jenner (2019) revealed that followers' satsfaction was greater with the leaders they perceived as transformational leaders rather than transactional leaders. Transformational leaders including principals also can make followers enthusiastic and optimistic (Jyoti \& Bhau, 2016) so that the followers can be highly motivated to do extra efforts, to work effectively, and to get satisfaction.

In terms of the associations between the other two leadership styles (transactional as well as laissezfaire) and the three leadership outcomes, little is known in earlier studies, particularly in the education context. Therefore, these findings provide empirical and theoretical contribution to the body of knowledge, particulalrly, concerning leadership theories by determining the extent to which leadership styles influence leadership outcomes.

It is finally expected that school leadership leads to effective leadership because effective leadership will positively contibute to making organizations including schools to become and remain competitive (Nandedkar \& Brown, 2018). Thus, it is recommended that principals exhibit transformational leadership to make them able to lead schools in rapid changes and encourage teachers to be creative 
and innovative (Albugami, 2020). In addition, Litz and Scott (2017) support this thought by saying that increased pressure in schools for changes through school reform needs principals to be transfomational.

\section{Conclusion}

Findings for an Indonesian school context are that the three leadership styles, as perceived by teachers, are significantly associated with the leadership outcomes (extra effort, satisfaction, and effectiveness). Either transformational or transactional leaderhip style is positively and significantly associated with the leadership outcomes, but laissez-faire leadership style is negatively and significantly associated with the leadership outcomes. Therefore, principals are recommended to exhibit transformational leadership style as well as transactional leadership style but to avoid laissez-faire leadership style when working with teachers.

These findings are congruent with what was expected from the literature review of the mainly Anglocentric Western literature on leadership styles and leadership outcomes. However, little is known in prior studies, particularly in the education context, concerning relationships between transactional as well as laissez-faire leadership styles and the three leadership outcomes.

Thus, the study of these associations examined in this paper will provide an important contribution to the body of knowledge, particulalry, school leadership including leadership outcomes and particularly to the development of the school system in Indonesia.

\section{Limitation and study forward}

This paper used quantitative research approach and is acknowledged for being limited to using the survey questionnaire so that it could not explain why and how principal leadership styles affect such leadership outcomes as extra effort, satisfaction, and effectiveness. However, the limitation is an opportunity for researchers to include in-depth interview for further research.

\section{Acknowledgement}

The author acknowledges Dr Richard Monypenny and anonymous reviewers for their worthwhile feedback on this manuscript.

\section{References}

Albugami, H. F. (2020). The impact of principal leadership styles on teachers performance in public elementary schools in Jeddah, Kingdom of Saudi Arabia. European Journal of Economic and Financial Research, 3(6), 48-65.

Alloubani, A. M. d., Abdelhafiz, I. M., Abughalyun, Y., Edris, E., \& Almukhtar, M. M. (2015). Impact of Leadership Styles on Leadership outcome (Effectiveness, Satisfaction and Extra Effort) in the Private Healthcare Sector in Jordan. European Scientific Journal.

Álvarez, O., Lila, M., \& Castillo, I. (2012). Los estilos de liderazgo de la Policía Local de la Comunidad Valenciana: Una aproxima-ción desde la Teoría del Liderazgo Transformacional. anales de psicología, 28(2), 548-557.

Amirul, S. R., \& Daud, H. (2012). A study on the relationship between leadership styles and leadership effectiveness in Malaysian GLCs. European journal of business and management, 4(8), 193-201.

Antonakis, J., Avolio, B. J., \& Sivasubramaniam, N. (2003). Context and leadership: An examination of the nine-factor full-range leadership theory using the Multifactor Leadership Questionnaire. The leadership quarterly, 14(3), 261-295.

Avolio, B. J., \& Bass, B. M. (2004). Multifactor leadership questionnaire: Manual and sampler set (3rd ed.). Redwood City: : Mind Garden, Inc.

Avolio, B. J., Bass, B. M., \& Jung, D. I. (1999). Re-examining the components of transformational and transactional leadership using the multifactor leadership questionnaire. Journal of occupational and organizational psychology, 72, 441.

Aya, F., \& David, P. S. (2007). Leadership preferences in Japan: an exploratory study. Leadership \& Organization Development Journal, 28(6), 508. 
Barnett, K., \& McCormick, J. (2003). Vision, relationships and teacher motivation: A case study. Journal of educational administration.

Bass, B. M. (1985). Leadership and performance beyond expectation. NY, USA: Free Press.

Bass, B. M. (1996). Is there universality in the full range model of leadership? International Journal of Public Administration, 19(6), 731-761.

Bass, B. M. (1997). Does the transactional--transformational leadership paradigm transcend organizational and national boundaries? The American Psychologist, 52(2), 130.

Bass, B. M. (1999). Two decades of research and development in transformational leadership. European Journal of Work and Organizational Psychology, 8 (1), 25.

Bass, B. M., \& Avolio, B. J. (2000). MLQ, Multifactor Leadership Questionnaire sampler set: Technical report, leader form, rater form, and scoring key for MLQ form $5 x$-short: Mind Garden.

Bass, B. M., \& Avolio, B. J. (2004). Multifactor leadership questionnaire: Manual and sampler set (4 ed.). CA: Mind Garden, Inc.

Bennett, T. M. (2009). The relationship between the subordinate's perception of the leadership style of IT managers and the subordinate's perceptions of IT manager's ability to inspire extra effort, to be effective, and to enhance satisfaction with management: Nova Southeastern University.

Biswas, M., \& Rahman, M. S. (2017). Role of Emotional Intelligence in Transformational Leadership and Leadership Outcomes. BGC Trust University Journal, 4, 187-206.

Casida, J., \& Parker, J. (2011). Staff nurse perceptions of nurse manager leadership styles and outcomes. Journal of Nursing Management, 19(4), 478-486.

Craig, H. J., Kraft, R. J., \& Du Plessis, J. (1998). Teacher development: Making an impact: US Agency for International Development.

Field, A. (2009). Discovering statistics using SPSS (3rd ed.). London: SAGE Publications Ltd.

Fukushige, A., \& Spicer, D. P. (2011). Leadership and followers' work goals: A comparison between Japan and the UK. The International Journal of Human Resource Management, 22(10), 21102134.

Garson, G. D. (2010, 25 January 2010). Testing of assumptions. Retrieved from http://faculty.chass.ncsu.edu/garson/PA765/assumpt.htm\#normal

Gemeda, H. K., \& Lee, J. (2020). Leadership styles, work engagement and outcomes among information and communications technology professionals: A cross-national study. Heliyon, 6(4), e03699.

Gray, D. E. (2004). Doing research in the real world. London: Sage.

Gurr, D., Drysdale, L., \& Mulford, B. (2005). Successful principal leadership: Australian case studies. Journal of educational administration, 43(6), 539-551. doi:10.1108/09578230510625647

Haj, S. J., \& Jubran, A. M. (2016). The Extent of Principals' Application of the Transformational Leadership and Its Relationship to the Level of Job Satisfaction among Teachers of Galilee Region. Journal of Education and Practice, 7(11), 114-119.

Hallinger, P. (2011). Developing a knowledge base for educational leadership and management in East Asia. School Leadership \& Management, 31(4), 305-320.

Hallinger, P., \& Walker, A. D. (2011). School leadership in Asia Pacific: Identifying challenges and formulating a research agenda. 31(4), 299-303.

Hamdani, M. R. (2018). Learning how to be a transformational leader through a skill-building, roleplay exercise. The International Journal of Management Education, 16(1), 26-36.

Hariri, H., Monypenny, R., \& Prideaux, M. (2012). Principalship in an Indonesian school context: can principal decision-making styles significantly predict teacher job satisfaction? School Leadership \& Management, 32(5), 453-471.

Hariri, H., Monypenny, R., \& Prideaux, M. (2014). Leadership styles and decision-making styles in an Indonesian school context. School Leadership \& Management, 34(3), 284-298.

Hariri, H., Monypenny, R., \& Prideaux, M. (2016). Teacher-perceived principal leadership styles, decision-making styles and job satisfaction: how congruent are data from Indonesia with the Anglophile and Western literature? School Leadership \& Management, 36(1), 41-62.

Hourani, R. B., \& Stringer, P. (2015). Professional development: Perceptions of benefits for principals. International Journal of Leadership in Education, 18(3), 305-339. 
Ismail, K., Ibrahim, A. H., Ali, A. H., Dawi, A. H., \& Ariff, M. S. M. (2015). Relationship Between Principal's Transformational Leadership Style and Teacher's Job Satisfaction. Advanced Science Letters, 21(7), 2459-2462.

Jenner, M. V. (2019). Transformational and Transactional Leadership Behaviors Influence Employee Job Satisfaction Within a Federal Government Organization. Saint Leo University.

Judge, T. A., \& Piccolo, R. F. (2004). Transformational and transactional leadership: A meta-analytic test of their relative validity. Journal of Applied Psychology, 89(5), 755.

Jyoti, J., \& Bhau, S. (2016). Empirical investigation of moderating and mediating variables in between transformational leadership and related outcomes. International Journal of Educational Management.

Keegan, A. E., \& Den Hartog, D. N. (2004). Transformational leadership in a project-based environment: a comparative study of the leadership styles of project managers and line managers. International journal of project management, 22(8), 609-617.

Kemdiknas. ( 2009). Jumlah kepala sekolah dan guru menurut status kepegawaian dan golongan tiap provinsi. Retrieved from http://www.kemdiknas.go.id/media/213896/index_smp_0809.pdf

Lin, P.-Y., MacLennan, S., Hunt, N., \& Cox, T. (2015). The influences of nursing transformational leadership style on the quality of nurses' working lives in Taiwan: a cross-sectional quantitative study. BMC nursing, 14(1), 1.

Little, L. M., Gooty, J., \& Williams, M. (2016). The role of leader emotion management in leadermember exchange and follower outcomes. The Leadership Quarterly, 27(1), 85-97.

Litz, D., \& Scott, S. (2017). Transformational leadership in the educational system of the United Arab Emirates. Educational Management Administration \& Leadership, 45(4), 566-587.

Mertkan, S. (2011). Tensions in leadership development: head teachers' experience in North Cyprus. School leadership and management, 31(1), 79-90.

Molero, F., Cuadrado, I., Navas, M., \& Morales, J. F. (2007). Relations and effects of transformational leadership: A comparative analysis with traditional leadership styles. The Spanish journal of psychology, 10(02), 358-368.

Muenjohn, N., \& Armstrong, A. (2008). Evaluating the structural validity of the multifactor leadership questionnaire (MLQ), capturing the leadership factors of transformationaltransactional leadership. Contemporary Management Research, 4 (1), 12.

Nandedkar, A., \& Brown, R. S. (2018). Transformational leadership and positive work outcomes. International Journal of Organization Theory and Behavior, 21(4), 315-327.

Ng, B., Wang, C. J., \& Liu, W. (2015). Self-regulated learning in Singaporean context: a congeneric approach of confirmatory factor analysis. International Journal of Research \& Method in Education, 1-17.

Nguni, S., Sleegers, P., \& Denessen, E. (2006). Transformational and transactional leadership effects on teachers' job satisfaction, organizational commitment, and organizational citizenship behavior in primary schools: The Tanzanian case. School effectiveness and school improvement, 17(2), 145-177.

Nielsen, K., Yarker, J., Brenner, S. O., Randall, R., \& Borg, V. (2008). The importance of transformational leadership style for the well-being of employees working with older people. Journal of advanced nursing, 63(5), 465-475.

Nordin, N. (2013). Transformational Leadership Behaviour and its Effectiveness Outcomes in a Higher Learning Institution. WCIK E-Journal of Integration Knowledge.

Northouse, P. G. (2007). Leadership: Theory and Practice (4th ed.). CA, USA: Sage Publications, Inc.

Pallant, J. (2007). SPSS survival manual: A step by step guide to data analysis using SPSS for Windows (Version 15) (3rd ed.). NSW: Allen \& Unwin.

Pashiardis, P. (1993). Group decision making: The role of the principal. International Journal of Educational Management, 7(2). doi:10.1108/09513549310026921

Price, J. L., \& Mueller, C. W. (1986). Absenteeism and turnover of hospital employees: JAI press.

Raihani. (2008). An Indonesian model of successful school leadership. Journal of educational administration, 46(4), 481-496. 
Ritchie, L. P., Mundeva, H., Lettow, M. v., Straus, S., Kip, E., \& Makwakwa, A. (2020). Impact of peer-trainer leadership style on uptake of a peer led educational outreach intervention to improve tuberculosis care and outcomes in Malawi: a qualitative study. BMC Health Services Research, 20, 1-10.

Scott, S. G., \& Bruce, R. A. (1995). Decision-making style: The development and assessment of a new measure. Educational and Psychological Measurement, 55(5), 818.

Siegrist, G. (1999). Educational leadership must move beyond management training to visionary and moral transformational leaders. Education, 120(2), 297-297.

Sofo, F., Fitzgerald, R., \& Jawas, U. (2012). Instructional leadership in Indonesian school reform: overcoming the problems to move forward. School Leadership \& Management, 32(5), 503522.

Spector, P. E. (1985). Measurement of human service staff satisfaction: Development of the job satisfaction survey. American Journal of Community Psychology, 13(6), 11.

Steyn, G. M. (2015). Creating a teacher collaborative practice in a South African primary school: The role of the principal. Journal of Asian and African studies, 50(2), 160-175.

Storey, A. (2004). The problem of distributed leadership in schools. School Leadership \& Management, 24(3), 249-265.

Thomas, C., \& Kearney, K. (2010). Effective principal support: What will it take. Leadership, 40(2), $8-11$.

Vullinghs, J. T., De Hoogh, A. H., Den Hartog, D. N., \& Boon, C. (2018). Ethical and passive leadership and their joint relationships with burnout via role clarity and role overload. Journal of Business Ethics, 1-15.

Williams, R. (2008). Leadership for school reform: Do principal decision-making styles reflect a collaborative approach? Canadian Journal of Educational Administration and Policy, 76(3), 9.

Wong, P.-M., \& Wong, C.-S. (2005). Promotion criteria and satisfaction of school teachers in Hong Kong. Educational Management Administration \& Leadership, 33(4), 423-447.

Yellen, S. B., Cella, D. F., Webster, K., Blendowski, C., \& Kaplan, E. (1997). Measuring fatigue and other anemia-related symptoms with the Functional Assessment of Cancer Therapy (FACT) measurement system. Journal of pain and symptom management, 13(2), 63-74. 